\title{
TAMAN HIKMAH: \\ RIWAYAT PESANTREN DAN TAREKAT
}

\section{LUKMAN HAKIM}

Dosen Pendidikan Ekonomi, Universitas Pamulang

ramadlanriqui@yahoo.com

\begin{abstract}
ABSTRAK
Banyak informasi yang menyebutkan bahwa Islam masuk ke Indonesia melalui jalur tarekat. Ajaran-ajaran tarekat yang berakar dari tradisi tasawuf ini kemudian menyebar, seperti benih yang tumbuh di lahan yang subur. Ini yang menyebabkan bahwa kajian dan pengamal tarekat di Indonesia tidak pernah sepi dari peminatnya. Di Indonesia, sebelum abad ke 18 dan 19, tarekat tumbuh dalam lingkungan istana. Namun setelah penjajahan kolonial Belanja berhasil menancapkan kuku kekuasaannya di Indonesia, tarekat bergeser ke pedalaman, dipelajari dan dipraktekkan di lingkungan pesantren. Pesantren memang memiliki akar sejarah yang panjang di Indonesia, khususnya dalam hal penyebaran agama Islam. Di samping itu, pesantren juga punya peran signifikan dalam konteks pendidikan keagamaan Islam. Beragaman khazanah intelektual Islam seperti aqidah, fiqh, tafsir, hadis, tasawuf dan lain sebagainya diajarkan dalam pesantren. Di samping itu, tarekat juga menjadi magnet lain bagi pertumbuhan pesantren di Nusantara. Tarekat memang tidak semata disuguhkan dalam konteks kajian ilmiah. Ia juga disuguhkan menjadi praktek yang hidup di tengah-tengah masyarakat untuk membimbing umat Islam berjalan untuk berjumpa dengan Allah dan memperbaiki akhlak melalui berbagai latihan tarekat. Pengajaran tarekat membutuhkan kedekatan antara murid dengan seorang mursyid. Dalam konteks itulah, pesantren menjadi lahan yang cocok bagi pengajaran tarekat, khususnya di Indonesia.
\end{abstract}

Kata Kunci: Tasawuf, Tarekat, Mursyid, Kiai dan Pesantren 


\section{PENDAHULUAN}

Banyak sarjana $\begin{array}{r}\text { Barat } \\ \text { keunikan }\end{array}$
menyaksikan
perkembangan Islam di Indonesia.
Berbagai perspektif tersaji dalam
beberapa kajian. Semua itu
mendeskripsikan betapa kaya
khazanah yang dimiliki oleh Islam di
Indonesia. Singkatnya, semua
menggambarkan universalisme Islam
dapat membaur dalam budaya lokal
untuk selanjutnya, dalam istilah
Nurcholish Madjid (biasa disapa Cak
Nur), meng-Indonesia. Islam
Indonesia, digambarkan lebih lanjut
oleh Cak Nur sebagai perpaduan
yang sempurna dari nilai-nilai
universal tanpa sekalipun kehilangan
elan kosmopolitanismenya
sebagaimana dulu, dalam peradaban Islam klasik berjumpa dengan budaya Helenisme di kota-kota yang baru saja dibuka oleh Islam seperti di Baghdad, Mesir, Damaskus dan lain sebagainya.

Tentu aspek historisitas kehadiran Islam di bumi Nusantara adalah salah satu faktor penentu pembentukan karakteristik Islam di Indonesia yang tetap menjejakkan kakinya dalam tradisi budaya setempat. Jikalah Islam menyebar di berbagai wilayah Timur Tengah lebih dominan disebabkan faktor politik, ini tidak terjadi di Indonesia. Tapi perbedaan latar belakang itu tidak melulu menjadi faktor tunggal dari perbedaan karakteristik Islam di
Indonesia dengan dunia Islam lainnya.

Infrastruktur perkembangan Islam, sejak awal kedatangannya memang dipersiapkan secara baik di Indonesia yang kemudian malah mempercepat pertumbuhannya. Ada dua faktor dalam hal ini. Pertama, pertumbuhan gilda-gilda yang dibangun oleh para saudagar dari Arab, Persia dan India. Gilda-gilda itu tidak hanya berfungsi sebagai rumah peristirahatan sementara dan kantor perwakilan dagang, tapi juga sering kali digunakan sebagai pusat dakwah penyebaran Islam dengan membawa ulama-ulama kompeten dari negeri-negeri tersebut. Kedua, ritual perjalanan Haji ke Tanah Suci yang bahkan telah terjadi jauh sebelum ada terusan Suez dan Kapal bermesin uap ditemukan.

Kedua faktor di atas sangat menentukan pemebentukan karakteristik Islam di Indonesia pada periode berikutnya. Dari gilda-gilda itu lahirlah lembaga pendidikan Islam yang kelak kita sebut sebagai pesantren. Sementara itu kepergian beberapa orang berhaji ke Tanah Suci, juga dimaksudkan untuk menuntut ilmu agama kepada guruguru yang otoritatif yang pada akhirnya juga membentuk karakteristik kajian keislaman di Indonesia pada periode selanjutnya. Biasanya para haji yang melanjutkan pendidikannya itu akan kembali ke tanah air setelah mendapatkan ijazah dari para syeikh di Tanah Suci untuk 
selanjutnya mengajarkan dan menyebarkan Islam kepada masyarakat. Sebagian besar mereka membangun basis pengajaran keagamaannya di dalam pesantren.

Berbagai disiplin keagamaan Islam mereka pelajari di Mekah dan Madinah, seperti fiqh, tafsîr, hadîts, aqîdah dan tashawwuf. Beberapa di antaranya mendalami dan masuk ke dalam tharîqah (selanjutnya ditulis tarekat). Selanjutnya tarekat banyak diajarkan di pesantren-pesantren di mana para kiai, tidak hanya berfungsi sebagai pimpinan pondok, juga menjadi mursyid tarekat.

Tentu pengajaran tarekat bukanlah pelajaran utama yang diberikan di pesantren-pesantren di Indonesia. Namun di sisi lain, tarekat menjadi salah satu daya tarik sebuah pesantren, di mana para santri tidak hanya datang untuk memperdalami ilmu agama, tetapi juga ingin masuk dan menyelam ke samudra spiritualitas Islam yang lebih luas untuk menggapai ma'rifah (selanjutnya ditulis menjadi makrifah).

Memang beberapa catatan sejarah membuktikan bahwa masuknya Islam ke Indonesia di antaranya melalui metode tarekat. Banyak mursyid (guru tarekat, selanjutnya ditulis menjadi mursyid) yang pernah bermukim dan dimakamkan di Indonesia memiliki jasa terhadap perkembangan Islam di Indonesia. Pengajaran tarekat dan ilmu keagamaan lainnya memang diawali dari perjumpaan para murid dan santri dengan ulama atau mursyid di gilda-gilda yang difasilitasi oleh para saudagar yang datang dari India atau Timur Tengah. Pesantren memiliki kontribusi yang cukup signifikan terhadap pertumbuhan tarekat di Indonesia. Oleh karenanya kajian atas pengaruh pertumbuhan tarekat dan perkembangan Islam di Indonesia yang tradisinya masih dipertahankan di beberapa pesantren layak untuk terus dieksplorasi lebih dalam. Tulisan ini diturunkan mengingat belum banyak kajian yang mendeskripsikan tentang signifikansi pesantren dalam mendesiminasikan ajaran-ajaran tarekat di Indonesia. Tapi tulisan ini hanya akan menyajikan pertumbuhan pengajaran tarekat di pesantren berdasarkan pendekatan sosial historis dengan menggunakan analisis studi kepustakaan. Bahkan di sisi lain, tarekat tidak hanya berkembang di lingkungan pesantren yang notabene didominasi oleh masyarakat tradisional. Ia terus merambah dan masuk ke dalam masyarakat modern dan kota. Belakangan ini malah tumbuh kajian atas urban sufism dengan beragam coraknya, menurut penulis, pastilah berakar dalam tradisi tarekat yang telah lama berakar pada tradisi Indonesia

\section{Tradisi Tarekat: Jalan Bersama} Mencapai Makrifah

Tarekat yang diajarkan oleh para Kiai di lingkungan pesantren di 
Indonesia berakar dari ajaran tashawwuf (sufisme, selanjutnya diIndonesiakan menjadi tasawuf) yang tumbuh sejak abad ke-2 H. Ajaran ini disebarkan pertama-tama oleh para shâlih , seperti Hasan al-Bashrî, Abû Yazid al-Busthâmî, Rabî'ah al'Adawiyyah, Ibrahîm bin Adhâm dan lain sebagainya. Doktrin pertama yang dikembangkan dalam sufisme adalah asketisme (zuhd). Lahirnya asketisme, menurut sebagian ilmuwan, merupakan respon atas kondisi sosial-politik umat Islam, khususnya penguasa Umayyah yang hidup dalam gelimang harta dan tahta. Kenyataan ini justru berbalik dari tradisi yang pernah dihidupkan oleh Nabi dan para sahabatnya di awal sejarah Islam.

Asketisme awal mengajarkan kita untuk tidak terlalu memutlakkan dan bergantung pada dunia karena sifatnya yang sementara. Oleh mereka, asketisme dipraktekkan dengan meninggalkan kemewahan dunia, hidup dengan zuhd, dan terus berupaya untuk membersihkan serta melunakkan hati dari godaan hawa nafsu. Dalam prakteknya asketisme memiliki beragam varian dan karakteristik sebagaimana yang dijalankan oleh para zâhid. Beragam karakteristik disimpulkan oleh alTaftazani ke dalam beberapa bagian ini:

"pertama, asketisme yang didasarkan pada ide menjauhi hal-hal duniawi, untuk meraih pahala akhirat dan memelihara diri dari azab api neraka. Ide ini berakar dari ajaranajaran al-Qur'ân dan al-Sunnah.

Kedua, asketisme bercorak praktis, para pendirinya tidak menaruh perhatian buat menyusun prinsip-prinsip teoritis atas aktivitasnya itu. Sarana-sarana praktis yang dimaksud adalah hidup dalam ketenangan dan kesederhanaan secara penuh, sedikit makan dan minum, banyak beribadah dan mengingat (dzikr) Allah, tunduk mutlak pada kehendak Allah dan berserah diri kepada-Nya.

Ketiga, motivasi asketisme adalah rasa takut. Yaitu rasa takut yang muncul dari landasan keagamaan secara sungguh-sungguh.

Keempat, asketisme merupakan cikal bakal dari lahirnya ajaran sufisme yang kemudian terus dikembangkan oleh para "pengembara" di jalan Allah.

Nicholson menyebut asketisme merupakan tangga pertama dari sufisme. Al-Taftazani menyebutkan bahwa, "tasawuf secara umum adalah falsafah hidup dan cara tertentu dalam tingkah laku manusia, dalam upayanya merealisasikan kesempurnaan moral, pemahaman tentang hakikat realitas, dan kebahagiaan ruhaniah." AlTaftazani lebih menekankan sufisme sebagai upaya pelatihan spiritualitas yang lebih menekankan pada kesempurnaan akhlak dan kebahagiaan hati.

Sementara itu Trimingham menyebutkan, "bahwa tasawuf 
adalah suatu situasi pengalaman spiritual yang paralel dengan aliran utama kesadaran Islam yang diturunkan dari wahyu dan dipraktekkan dalam syariah dan teologi." Ditambah lagi, bahwa ada kecenderungan dalam sufisme untuk manunggal antara Tuhan dan manusia. Pendapat Trimingham tersebut bercorak filosofis, lebih cenderung pada kajian mistisisme. Memang dalam prakteknya banyak kaum sufi seperti Abû Yazid alBusthâmî, al-Hallâj, Ibn al-`Arâbî mengembangkan faham tentang kesatuan wujud antara manusia dan Tuhan dalam hulûl, fanâ' al-baqâ dan al-ittihâd yang kemudian banyak dikaji dan dihayati oleh para pelaku mistisisme. Tapi pandangan mereka dalam sufisme bukanlah mainstream, bahkan ada yang mengatakan sesat, sekalipun tuduhan atas kesesatannya sering kali tidak mendasar. AlTaftazani menegaskan bahwa sufisme jelas berbeda dengan mistisisme dalam hal sumber. Sufisme lahir dari kesadaran keagamaan sementara mistisisme lahir dari filsafat.

Jalan tasawuf menuju pengalaman spiritual "berjumpa" dengan Allah seperti menapak jalan berliku dan terjal. Tidak semua orang dapat melalui jalan itu. Ada yang mencoba melaluinya, tapi jika tak ada petunjuk dari seorang guru, bisa saja arah jalan yang ditapaki itu justru membawanya menjauh dari tujuan semula berjumpa dengan
Allah. Oleh karenanya para pendaki (sâlik, murid) itu membutuhkan bimbingan dari seorang guru sufi (mursyid).

Dalam konteks itulah kemudian bermunculan pusat-pusat pendidikan "calon sufi" kepada beberapa tokoh sufi di sekitar abad ke-6 dan 7 H. Pusat-pusat pendidikan itu kemudian dikenal dengan nama ribâth, zawiyyah, tekke dan khanaqah. Menurut Trimingham, terdapat perbedaan-perbedaan mendasar antara istilah-istilah pusat pendidikan tersebut. Ribâth seringkali diartikan sebagai rumah peristirahatan dan pusat latihan ruhani bagi calon sufi. Sementara khanaqah sering kali didefinisikan sebagai rumah persinggahan bagi para pengelana (musafir fi Allah) sekedar untuk beristirahat, berdiskusi dan memperdalam ilmu tasawuf oleh seorang mursyid yang mengelola tempat tersebut. memang ada kemiripan konsepsional antara ribâth dan khanaqah, sebagai sama-sama tempat persinggahan yang difungsikan sebagai tempat belajar atau pertemuan para sufi. Sedangkan zawiyyah, adalah rumah yang ditinggali oleh seorang mursyid bersama dengan murid-muridnya. Biasanya zawiyyah dibangun jauh dan terisolasi dari penduduk, tapi ada juga yang menyebutnya sebagai rabîthah. Biasanya di tempat-tempat tersebut dilaksanakan pertemuanpertemuan ilmiah dan ruhaniyah secara periodik. 
Dari pusat-pusat pendidikan itulah kemudian berkembang berbagai mazhab dalam sufisme yang kelak disebut dengan tarekat. Kata tarekat, mengutip dari Lindung Hidayat Siregar, berakar dari alQur'ân. Kata itu disebut sebanyak sembilan kali di antaranya, Q.S. alNisâ (4): 168-169; Q.S. Thâhâ (20): 63, 77 dan 104; Q.S. al-Mu'minûn (23): 17, Q.S. al-Ahqâaf (46): 30, dan; Q.S. al-Jîn (72): 11 dan 16.

Kata "Tarekat" secara etimologis disebut dalam berbagai makna: (1) jalan dan cara (alkayfiyyah); (2) metode dan sistem (al-uslûb); (3) mazhab, aliran dan haluan (al-madzhab); dan (4) keadaan (al-hâhlah). Dalam terminologi Islam ada beberapa istilah yang memiliki padanan makna yang sama dengan tarekat, di antaranya syarîah dan sunnah. Syarî ah biasa diartikan sebagai jalan utama. Beberapa ulama mengistilahkannya sebagai "jalan raya" di mana berbagai macam bentuk ajaran Islam seperti aqîdah, fiqh, ibâdah dan lain sebagainya. Biasanya syarîah lebih menekankan pada aspek formalitas keagamaan. Sunnah juga diartikan sebagai jalan. Tapi Fazlur Rahman lebih menekankan istilah sunnah itu pada aspek-aspek tradisi yang dipraktekkan oleh Nabi dan sahabat.

Jikalah syarîah diartikan sebagai jalan utama, maka tarekat adalah cabang dari jalan tersebut. Jika syarîah diartikan sebagai uraian, maka tarekat adalah pelaksanaannya. Jalan setapak yang dilalui oleh penganut tarekat itu, menurut Annemerie Schimmel, pastilah berpangkal pada syarîah. Tarekat dan syarî‘ah adalah perpaduan yang tidak dapat dipisahkan. Tujuan dari tarekat untuk menggapai makrifah dan hakikat harus digapai melalui jalan yang telah dipetakan dalam syarîah. Dalam hal ini Schimmel mengutip sebuah syair dari Turki sebagai berikut:

Syariat: milikmu milikmu, milikku milikku

Tarekat: milikmu milikmu, milikku, milikku

Makrifah: tak ada milikku atau milikmu

Trimingham mendefinisikan tarekat sebagai "metode praktis untuk membimbing seorang sâlik dengan menelusuri suatu jalan berpikir, merasa dan bertindak, secara bertahap (dengan melalui jalan maqâmât). Sedangkan Aboebakar Atjeh, mengartikan "tarekat sebagai jalan, petunjuk dalam melakukan sesuatu ibadat sesuai dengan ajaran yang ditentukan dan dicontohkan oleh Nabi dan dikerjakan oleh sahabat dan tabi'in, turun-temurun sampai kepada guruguru secara berantai". Sementara menurut Rahman, tarekat adalah "jalan sufi" yang menuntun manusia menuju pertemuan (communion) dengan Allah. Tapi jalan yang dimaksud hanya dapat terealisasi 
secara bersama dalam sebuah persaudaraan yang terorganisasi dengan baik.

Dengan demikian, dapat disimpulkan bahwa tarekat adalah tradisi keislaman yang berpangkal pada ajaran Nabi, selanjutnya dipraktekkan oleh para sahabat, tabi in dan sampai generasi saat ini. Hal ini menjelaskan bahwa keilmuan dalam tarekat memiliki nasab yang langsung terhubungan dengan Nabi.

Tarekat merupakan jalan yang dipilih oleh para sufi untuk mentransmisikan spiritualitas Islam secara lebih masif. Mengapa harus melalui jalan tarekat? Tidakkah dengan seseorang melaksana-kan ibadah, seperti shalat, puasa, dan membaca $d z i k r$ akan memancar dalam dirinya nilai-nilai spiritualitas yang teref-leksi dalam kesalehan individual? Bukankah ibadah dilaksanakan untuk menegaskan keEsa-an Allah, membersihkan hati dan meningkatkan kualitas akhlak individu?

Ajaran tarekat seluruhnya mengarah sebagaimana dimaksud di atas. Tarekat memberi bimbingan para murid untuk taqarrub (mendekat) kepada Allah, pasrah dalam setiap qadla dan qadr yang telah ditentukan-Nya. Dalam konteks itulah Aboebakar Atjeh menegaskan bahwa pokok-pokok ajaran tarekat adalah sebagai berikut:

"Pertama, mempelajari ilmu pengetahuan yang bersangkut paut dengan pelaksanaan semua perintah.
Kedua, mendampingi guru dan teman setarekat untuk melihat bagaimana melakukan suatu ibadah. Ketiga, meninggalkan segala rukhshah dan ta'wîl untuk menjaga dan kesempurnaan amal. Keempat, menjaga dan mempergunakan waktu serta mengisinya dengan segala wirid dan doa guna mempertebal khusyû dan hudlûr. Kelima, mengekang diri jangan sampai keluar tergerak untuk melakukan yang didasari hawa nafsu dan menjaga diri dari melakukan kesalahan (dosa)."

Tujuan dari tarekat pastilah untuk mendapatkan pengalaman spiritual yang darinya akan merefleksikan kualitas lahiriyah dan batiniah setiap individu yang melaluinya. Tapi bagi Rahman yang terpenting dari itu semua adalah praktek dan tujuan dari tarekat itu harus memberikan arti pada tindakan sejarah.

Jalan untuk taqarrub dalam tarekat dilakukan di bawah bimbingan seorang mursyid. Dalam konteks itulah tarekat tumbuh. Semula tasawuf sebagai tangga menggapai makrifah hanya dapat dilalui oleh para elit kerohanian. Tapi dengan tarekat, jalan itu terbuka dan bisa dilalui oleh siapa saja yang mau berdisiplin mengikuti seluruh petunjuk dan bimbingan dari seorang guru.

Mengapa harus ada mursyid dalam tarekat? Dan siapa yang layak untuk menjadi mursyid? Bagaimanapun perjalanan ruhani 
berjumpa Allah itu seperti jalan yang berkelok, terkadang tajam, terjal, mendaki dan menurun. Bagi mereka yang belum pernah menapaki jalan itu sudah barang tentu membutuhkan penuntun agar perjalanannya sampai pada tujuan. Siapa yang menjadi penunjuk arah dalam perjalanan itu, pastilah mereka yang pernah melewati dan hafal setiap kelok dan roadmap yang harus dilalui. Dan para mursyid itu bertindak sebagai penuntun jalan yang dimaksud.

Para murid dalam tarekat biasa disebut sebagai pendaki pemula. Sementara seorang mursyid adalah orang yang pernah mencapai rute yang dilakukan oleh seorang murid. Fungsi seorang mursyid dalam tarekat tidak sekedar memberi bimbingan dan petunjuk, menurut Schimmel, ia seperti bidan yang membantu melahirkan "hati yang benar" dan seperti ibu yang senantiasa memberi susu atas dahaga ruhani bagi anaknya.

Karena rute yang dilalui itu penuh kelok, maka terlalu berbahaya bagi seorang murid dibiarkan mendaki seorang diri tanpa pemandu dan bimbingan. Bisa saja dalam perjalanan itu, seorang murid tersesat. Dalam sebuah syair yang dikutip oleh Schimmel menggambarkan bahwa sebuah perjalanan ruhani akan sia-sia jika tidak dilakukan tanpa penuntun.

"Barang siapa berjalan tanpa pemandu

Memerlukan dua ratus tahun untuk

\section{Perjalanan dua hari"}

Karena jalan itu panjang dan sulit, seorang murid dituntut ketaatan dan kesetiaan kepada mursyid serta terus berjuang tanpa putus asa. Dengan demikian seorang murid akan mendapatkan peningkatan dan kemajuan dalam tarekat.

Seorang murid, pada akhirnya bisa saja menjadi seorang mursyid. Dalam tradisi tarekat tidak ada standar dan mekanisme yang pasti tentang penunjukan seorang murid dari guru. Sudah barang tentu, seseorang dapat ditahbiskan menjadi seorang mursyid, sebelumnya telah merampungkan berbagai tahapan yang disyaratkan dalam sebuah tarekat. Misalnya telah menjalankan seluruh murâqabah, khalwat, tebusnafsu, safar dan lain sebagainya. Intinya yang bersangkutan telah menamatkan seluruh pendidikan yang diberikan oleh seorang mursyid sebelumnya.

Ada banyak jalur dan cara calon murid dapat ditetapkan sebagai mursyid. Ada jalur melalui mimpi. Ini terjadi pada diri Syeikh Tijani, pendiri tarekat Tijaniyyah. Kemursyidannya terjadi ketika yang bersangkutan bermimpin berjumpa Rasulullah. Ada pula dengan cara seorang mursyid sebelumnya mengangkat seorang atau beberapa orang sebagai khalifahnya (pengganti). Di antaranya terjadi dalam Tarekat Qadiriyyah dan Naqsabandiyyah di mana Syeikh Ahmad Khatib Sambas mengangkat 
beberapa muridnya seperti Abdul Karim Tanara. Posisi khalifah memang sedianya dipersiapkan kepada murid untuk melanjutkan tarekat. Dan setelah sang mursyid mangkat, biasanya khalifah otomatis dapat menjadi mursyid.

Rutinitas antara seorang mursyid-murid dalam hal memberikan bimbingan ruhani dan mengevaluasi murâqabah yang dilakukan oleh seorang murid, pada akhirnya menumbuhkan etos kebersamaan di antara mursyidmurid dan di antara para murid dalam sebuah ikatan yang dinamakan tarekat. Hal ini kemudian juga menegaskan, bahwa tarekat tidak hanya tumbuh sebagai pusat latihan rohani. Ia juga tumbuh menjadi sebuah organisasi yang aturannya dibuat oleh para pendiri atau syeikh. Aturan-aturan pengorganisasian yang dikenakan begitu longgar, malah semangat kekeluargaan justru tampak lebih dominan dalam organisasi tarekat. Dengan cara itu, maka tarekat tumbuh, bahkan mencapai masa keemasannya di abad ke-7 dan ke-8 H.

\section{Tradisi Pesantren dan Pendidikan Tarekat di Indonesia}

Warna mistisisme yang begitu kental dalam perkembangan Islam di Indonesia merupakan tipologi Islam di Nusantara. Nor Huda menyebut bahwa masuknya Islam di wilayah Nusantara disebarkan oleh para pengamal tarekat. Bahkan menurut catatan, pertumbuhan awal Islam di Indonesia terjadi ketika tarekat sedang memasuki masa keemasannya baik itu di Haramayn, di Baghdad dan di Kuffah, khususnya di abad ke-13.

Jika tarekat berkembang di Timur Tengah, Persia dan Afrika Utara melalui tempat-tempat seperti zawiyyah, khanaqah, ribâth, dan tekke, maka di Indonesia, bibit tarekat disemai di dalam pesantrenpesantren. Ada kemiripan antara pesantren dengan tempat-tempat dan penyemaian benih-benih sufisme itu, yaitu sama-sama diasuh oleh seorang tokoh kharismatik keagamaan dan kerohanian. Tokoh itu di Indonesia dikenal dengan nama kiai (Jawa), buya (Sumatera), tuan guru (Lombok) atau ajengan (Jawa Barat). Disamping itu keduanya memiliki kesamaan pada pola kehidupan kolektif antara mursyid-murid, dengan kiai-santri yang hidup dalam satu atap yaitu pesantren. Dengan cara itu, kiai akan mudah mengajarkan ilmu-ilmu keagamaan, sekaligus juga menjadi pembimbing pertumbuhan ruhaniah para santri untuk pada waktunya akan diijazahkan dan dikembalikan kepada masyarakat. Bimbingan atas pertumbuhan ruhaniyah santri, biasanya dilakukan melalui jalan tarekat. Dan para kiai sendiri yang tampil sebagai mursyid. 


\begin{abstract}
Pesantren merupakan lembaga pendidikan yang khas Indonesia. Berbagai lembaga pendidikan keagamaan, termasuk khanaqah dan lain sebagainya, di Timur Tengah, India dan Afrika Utara, pertumbuhannya amat sangat tergantung dari pemerintah dan rezim yang berkuasa. Sementara pesantren didirikan di Indonesia atas swadaya masyarakat, oleh karenanya sering kali bersifat independen terhadap kekuasaan. Setidaknya hal itu dibuktikan melalui catatancatatan sejarah pendirian berbagai pesantren di Indonesia.
\end{abstract}

Banyak catatan menyebutkan perkembangan Islam di Indonesia direspon dengan pertumbuhan pesantren. Catatan awal tentang pertumbuhan Islam hampir selalu merujuk pada pendirian pesantrenpesantren atau lembaga-lembaga pendidikan keagamaan lainnya. Banyak tesis yang menyebutkan soal penerimaan masyarakat Indonesia atas Islam di abad-abad silam. Dari sekian tesis itu, tidak ada satupun yang secara pasti menyebutkan sejak kapan Islam pertama kali diterima oleh masyarakat di Nusantara, siapa dan dari negeri mana kah orang yang pertama kali membawa agama itu ke Indonesia dan lain sebagainya.

Banyak ahli yang menyebutkan Islam masuk ke wilayah Nusantara melalui jalur dagang. Beberapa laporan atau kajian menyebutkan, jauh sebelum Islam hadir di Nusantara para saudagar di

Indonesia dan bangsawan di Timur Tengah, China dan India sudah terkoneksi satu dengan lainnya untuk berbisnis hasil bumi, khususnya rempah-rempah dan barus, bahan untuk membuat parfum. Tapi ada juga yang menyangkal tesis tersebut dengan menyebutkan bahwa jalur dagang bukan faktor tunggal bagi masuknya Islam di Indonesia. Jalur perdagangan antar negara dan benua yang terjadi di berbagai wilayah di Nusantara memang menyebabkan Islam mudah masuk di Indonesia. Tapi jika tidak ditopang oleh budaya masyarakat di Nusantara yang religius sudah barang tentu "keyakinan baru" itu akan tidak mendapat respon positif dari masyarakat lokal. Martin van Bruinessen pernah menjelaskan salah satu faktor penerimaan masyarakat lokal atas nilai-nilai Islam yang dibawa oleh pendakwah dari India dan Timur Tengah itu tidak akan direspon baik jika tidak memiliki pemahaman kosmologi yang sama, yaitu soal asal-usul bermula dan berakhir manusia. Seperti kapal yang layarnya telah berkembang dan bersiap untuk berlayar, nilai-nilai filosofi keagamaan masyarakat lokal, seperti menjadi arus laut yang mempercepat pertumbuhan Islam di bumi Nusantara.

Bermula dari jalur
perdagangan itulah penduduk
Indonesia, khususnya di wilayah-
wilayah pesisir berkenalan dengan
Islam. Mulanya, para saudagar yang


singgah di berbagai pelabuhan itu banyak ditumpangi para ulama yang kemudian menyebarkan Islam. Berkat jasa para saudagar rumahrumah penginapan dibangun sebagai tempat transit dan gilda. Penginapan itu, dalam bahasa Arab disebut "funduq", yang berarti hotel, diambil dari bahasa Yunani "pandokeyon", kemudian kata itu dikenal dalam bahasa Indonesia menjadi “pondok". Banyak penduduk di sekitar pelabuhan mampir ke pondok untuk sekedar menyelesaikan urusan bisnis, mengenal dan belajar menimba agama Islam, agama yang baru datang ke bumi Nusantara, dari para ulama yang ikut dalam rombongan tersebut. Selanjutnya berdirilah pondok sebagai institusi keagamaan Islam yang menurut Cak Nur, sebelumnya diintegrasikan terlebih dahulu dengan "padepokan", sebuah konsep pendidikan keagamaan dalam tradisi Hindu-Budha, yang telah memiliki akar sejarah yang cukup lama di Indonesia.

Berdasarkan integrasi itu muncullah istilah pesantren. Cak Nur menjelaskan, bahwa orang-orang bijak yang memiliki kecakapan dalam tulis-baca, dalam tradisi Hindu-Budha, disebut sebagai kaum shastri. Kaum shastri ini dikenal juga dengan nama cantrik yang dapat berarti sebagai orang sedang berguru atau magang. Mereka belajar dari seorang guru yang arif-bijaksana yang disebut dengan kiyahi. Mereka belajar dan menempa pengalaman hidup itu dalam sebuah tempat yang disebut dengan padepokan cantrik. Selanjutnya, setelah Islam datang, berubahlah penamanaan itu menjadi pondok pesantren: penginapan dan tempat kaum santri belajar kepada seorang 'âlim, yang kita kenal sekarang dengan nama kiai. Selanjutnya tidaklah terlalu berlebihan jika ada yang mengatakan bahwa umur pesantren di Indonesia adalah sama tuanya dengan kedatangan Islam di Indonesia.

Keilmuan

yang dikembangkan di lingkungan pesantren pastilah memiliki nasab keilmuan dengan dari mana Islam berasal: haramayn, dalam skala yang lebih luas adalah Timur Tengah. Kitab-kitab yang dikajipun sebagian besarnya merupakan karangan ulama-ulama mu`tabarah yang tumbuh dan berkembang dalam tradisi intelektual Timur Tengah di masa itu. Jikalah ada kitab-kitab yang ditulis oleh para ulama (kiai) Indonesia, biasanya hanya dijadikan kitab pendamping bagi santri setelah dia menamatkan kajian atas kitabkitab mainstream dalam keagamaan Islam. Kitab-kitab yang dibaca itu langsung dari bahasa aslinya. Karenanya, pesantren selain juga mengajarkan ilmu-ilmu keagamaan juga mengajarkan para santrinya tata bahasa dan sastra Arab.

Oleh karenanya berbagai mazhab keilmuan dalam Islam seperti dalam tradisi kalam, tasawuf, fiqh dan lain sebagainya pastilah 
akan berkiblat pada salah satu mazhab yang menjadi arus utama dalam bidang keilmuan yang telah mapan di Timur Tengah. Sebagai contoh, fiqh yang diajarkan Indonesia mayoritasnya adalah bermazhab Syafi î. Pandangan kalam didominasi mazhab ahl- 'l-sunnah wa 'l-jamâ'ah atau lebih dikenal dengan mazhab Asy`ariyah. Sementara dalam bidang tasawuf lebih dekat pada perspektif yang diberikan oleh al-Ghazâlî. Tentu mazhab-mazhab lain yang menjadi mainstream di belahan dunia Islam lain bukan berarti tidak tumbuh, tapi jumlahnya terlalu sedikit, agak sukar untuk ditelusuri lebih dalam.

Perjumpaan intelektualisme Islam di Indonesia dimulai dari pertemuan-pertemuan sementara yang dikenalkan oleh para syeikh yang datang ke funduq. Pertemuan itu hanya lapisan awal dari pertumbuhan intelektualisme keislaman di Indonesia. Berikutnya dimulailah babak petualangan memburu ilmu agama sampai ke haramayn melalui perjalanan ibadah haji.

Perjalanan ke Tanah Suci yang dilakukan oleh orang-orang Indonesia memiliki banyak maksud selain untuk beribadah haji. Martin van Bruinessen pernah menguraikan antara lain adalah untuk mendalami ilmu agama dan mencari legitimasi politik, khususnya kesultanan Islam yang ada di bumi nusantara dari sumber ajaran Islam berasal.
Kedatangan orang-orang Islam ke Tanah Suci, menurut catatan sudah dimulai dari abad ke-17. Bahkan ada yang mengatakan jauh sebelum itu, sudah ada orang Indonesia yang pergi merantau untuk ibadah haji dan belajar ilmu agama.

Perjalanan haji di masa itu tidak mudah. Rute yang dilewati adalah samudra luas dan ganas. Tidak sedikit laporan yang menyebutkan beberapa jemaah haji dari Indonesia yang meninggal di perjalanan ketika berangkat dan pulang ke tanah air atau tidak pernah ditemukan kabar beritanya. Tentu dengan berbagai sebab, seperti sakit di tengah perjalanan, kapal yang ditumpangi hancur dihantam badai, dirampok di tengah perjalanan dan lain sebagainya. Tapi ketika teknologi perkapalan sudah jauh lebih maju, jemaah haji Indonesia meningkat beberapa kali lipat dari sebelumnya. Di samping itu memang ada hambatan lain yaitu kebijakan kolonial Belanda di Indonesia yang membatasi keberangkatan pergi haji. Namun itu sama sekali tidak pernah menyurutkan niat orang Indonesia untuk pergi haji ke Mekkah.

Sebagian besar jemaah haji Indonesia tidak segera pulang ke tanah air. Mereka bermukim di Mekah-Madinah untuk menuntut ilmu agama dari para syeikh. Seperti seorang yang tengah dahaga, seluruh ilmu keagamaan yang diajarkan itu direguk habis. Sampai waktunya mereka berpamitan pulang setelah 
mendapatkan ijazah dari para guru dari haramayn itu. Beberapa ulama besar Indonesia yang pernah berguru dan menetap dalam tempo yang cukup lama, bahkan di antaranya balik kembali untuk memperdalam keilmuannya, dan pada akhirnya menetap hingga akhir hayatnya di Mekkah atau Madinah. Adapun ulama-ulama yang dimaksud di antaranya adalah Hamzah Fansuri, `Abul Ra ûf al-Singkilî, Nûruddîn alRanirî, Syeikh Yûsuf al-Makasarî, Syeikh Nawâwî al-Bantani, Syeikh Ahmad Khâtib Sambas, 'Abd-u '1Shamad al-Falimbanî, Aḥmad Khâthib al-Minangkabawî dan lain sebagainya. Di antara nama-nama tersebut bahkan melanjutkan karir intelektualitasnya di Tanah Suci, bahkan berhasil memperoleh posisi terhormat sebagai salah satu ulama yang pernah ada di tanah Arab. Salah satu catatan tentang perjalanan haji itu pernah ditulis oleh salah seorang ulama Indonesia yang pernah ke sana, ini terlihat dari potongan syair yang pernah ditulis oleh Hamzah Fansuri:

Hamzah Fansuri di dalam Mekkah

Mencari Tuhan di Bait al-Ka`bah

Di Barus ke Qudus terlalu payah

Akhirnya dapat di dalam rumah

Di samping menuntut ilmu-ilmu agama, sebagian besarnya juga masuk menjadi pengikut tarekat yang kala itu banyak menyebar dan diajarkan oleh ulama-ulama di tanah suci. Beberapa ulama beken yang juga tercatat sebagai mursyid tarekat dan pernah menjadi guru dari muridmurid jâwî (sebutan untuk orangorang Indonesia yang bermukim di Arab) adalah Ahmad al-Qusyasyî, Ibrahîm al-Kuranî, Muhammad alSammman, 'Abd al-Wahab alSya'ranî, Zakariyya al-Anshârî, dan lainnya. Ulama-ulama tersebut hidup pada kurun waktu sekitar abad ke-17 dan 18.

Berikut ini adalah contoh dari beberapa murid dari Nusantara yang belajar pada ulama di Haramayn. AlSingkilî berguru secara langsung kepada al-Qusyasyî dan al-Kuranî. Keduanya adalah mursyid dari tarekat Syattariyyah. Karenanya berkat al-Singkilî tarekat Syattariyyah berkembang pesat di wilayah utara Sumatra.

Selain itu, ada juga Syeikh Yûsuf al-Makasarî yang juga berguru kepada al-Kuranî. Di samping itu ia juga banyak mendapatkan ijazah tarekat dari berbagai mursyid. Ini disebabkan karena Yusuf setelah menamatkan pendidikannya di Mekkah, dia melanjutkan petualangannya berguru ilmu agama dan tarekat sampai ke Damaskus. Beberapa ijazah tarekat yang diperoleh al- Makasarî adalah Qadîriyyah, Naqsabandiyyah, Syattariyyah, dan Khalwatiyyah.

Nama lain yang juga menjadi mursyid tarekat di Indonesia yang paling terkenal adalah Syeikh Ahmad Khâtib Sambas. Ia menghabiskan sebagian besar masa dewasanya di Mekkah dengan 
berguru ke berbagai ulama yang menyebar di tanah Arab dalam berbagai disiplin keagamaan. Karir intelektualnya sebagai ulama tidak hanya di kalangan jâwî, tapi juga di kalangan bangsa Arab. Dari tangannya ia melebur dua tarekat mu'tabarah yang ada dalam tradisi sufisme dengan nama tarekat qadîriyyah wa naqsabandiyyah. Inilah satu-satunya tarekat mu'tabarah yang lahir dari rahim ulama Indonesia. Dalam perjalanannya, Khâtib Sambas banyak mengangkat khalîfah (pengganti dari syeikh atau pendiri) seperti 'Abdul Karim Tanara (alBantani) dan selanjutnya beliau mengangkat beberapa mursyid lain seperti Kiai Tolhah dari Cirebon dan Kiai Ahmad Hasbullah dari Madura. Kemudian dari murid-muridnya itu tarekat ini berkembang pesat, bertambah masyhur, bahkan memiliki jemaah yang signifikan di Indonesia.

Dari tangan guru-guru tarekat yang telah menamatkan pendidikan dari Tanah Suci itu, tarekat dikembangkan di Indonesia, dimulai dari abad 17-18. Pada awalnya pengamal tarekat di Indonesia terbatas pada lingkungan istana. Bagaimanapun, ini dipengaruhi oleh mursyid tarekat yang pada awalnya bekerja di lingkungan istana sebagai penasehat dan pegawai kerajaankerajaan Islam di Nusantara. Sebut saja seperti Syeikh Yûsuf alMakasarî dan 'Abdul Karim al-
Bantani pernah berkarir di kesultanan Banten. Hamzah Fansurî, al-Singkilî dan al-Ranirî pun juga pernah menjabat sebagai qadlî dan penasehat raja di kesultanan di Aceh. Di samping itu para sultan di kerajaan-kerajaan Islam di Indonesia yang pernah meminta legitimasi politik dari para syeikh di haramayn pun mengikat perjanjian dengan cara masuk menjadi jemaah salah satu tarekat mu`tabarah yang ada, yang dibawa oleh para mursyid yang telah berbai`at di Tanah Suci.

Tarekat tumbuh di tanah yang subur, di Indonesia. Di awal perkembangannya memang mendapat sokongan penuh dari penguasa. Dari dukungan penguasa saat itu, tarekat menyebar secara massif ke tengah-tengah masyarakat. Bahkan ketika pemerintah kolonial bercokol di bumi Nusantara. Tarekat mengambil peranan utama perlawan terhadap pemerintahan kolonial itu. Para mursyid tarekat maju di barisan terdepan mengkonsolidasi perlawanan tersebut. Sebelum tentara-tentara rakyat maju ke medan laga, ada cerita bahwa para mursyid melakukan pembai atan tarekat. Berkat bai at dan doa dari sang guru itu, spirit perjuangan tumbuh dan mereka tampil gagah berani. Memang banyak cerita mistis yang muncul dibalik peristiwa itu, di antaranya mereka mendapatkan berbagai kesaktian seperti kebal terhadap senjata, bisa menembus 
pertahanan lawan tanpa terlihat kasat mata dan lain sebagainya.

Perlawanan itu memang mampu diredam oleh pemerintah kolonial Belanda. Dan sekalipun kerajaan-kerajaan Islam yang bercokol di Nusantara, satu-persatu mampu ditaklukkan, seperti di Aceh, Banten, Makasar dan lain sebagainya, tidak berarti tradisi tarekat ikut meredup. Ia terus tumbuh bersamaan dengan perkembangan Islam yang terus masuk ke pedalaman di kepulauan Indonesia. Tarekat berkembang bersamaan dengan menjamurnya pendirian pondok pesantren. Jika di masa sebelumnya para mursyid memiliki jabatan-jabatan politik dan hidup di lingkungan istana, maka pada periode selanjutnya para mursyid hidup di lingkungan pesantren. Figur mursyid kemudian digantikan oleh seorang kiai yang mengasuh pondok pesantren.

Bagaimanapun pesantren memiliki infrastruktur bagi pertumbuhan dan pendidikan tarekat. Infrastruktur seperti pondok, masjid, santri, kiai dan kitab yang dikaji, tidak lain adalah pilar-pilar penyangga bangunan pesantren membuat tarekat semakin tumbuh dan berkembang dengan baik. Institusi pesantren jelas berbeda dengan lembaga pendidikan agama lainnya seperti madrasah dan sekolah. Pesantren selalu identik dengan para murid (santri) yang hidup dan menetap di pondok dalam kurun beberapa waktu. Pondok adalah jantung dari pesantren. Di pondok para santri saling berinteraksi, dengan kiai sebagai pengasuh, dan belajar dan mengaji kitab-kitab keagamaan secara bersama-sama.

Pilar selanjutnya dari pesantren adalah santri. Pondok merupakan tempat para santri beraktivitas belajar ilmu keagamaan dan kehidupan. Zamakhsyari Dhofir menjelaskan ada tiga alasan santri mondok di pesantren. "Pertama, ingin mempelajari kitab-kitab secara mendalam kepada seorang kiai. Kedua, memperoleh pengalaman hidup dalam berbagai hal. Ketiga, ingin lebih fokus dalam belajar tanpa diganggu oleh urusan-urusan di luar studi".

Pilar ketiga adalah masjid. Dalam sejarah perkembangan Islam, masjid tidak hanya berfungsi sebagai tempat ibadah untuk melaksanakan shalat lima waktu dan shalat Jumat. Masjid juga sesekali berfungsi sebagai tempat pertemuan, dan dari masjid terkadang kehidupan ekonomi tumbuh. Di sisi lain, jauh sebelum institusi pendidikan tumbuh, masjid dijadikan sebagai sarana untuk menuntut ilmu pengetahuan. Di lingkungan pondok pesantren, masjid merupakan bangunan penting dan sentral kegiatan. Para kiai mendidik santri di masjid dalam berbagai hal. Dan biasanya bangunan pertama yang dibangun di lingkungan pesantren adalah masjid. 
Pilar keempat adalah Kiai itu sendiri. Kiai seringkali dinisbatkan kepada seorang ‘âlim yang memiliki pengetahuan keagamaan dan kebijaksanaan. Atas latar belakang inilah para santri datang ke pesantren untuk berguru kepada kiai. Selanjutnya, yang kelima adalah kitab yang dikaji. Ada beberapa pesantren yang hanya mengajarkan kitab-kitab khusus. Biasanya kitabkitab yang diajarkan itu identik dengan kepakaran seorang kiai dan penguasaan atas kitab yang dimaksud Misalkan, ada beberapa pesantren yang identik dengan pengajian tafsir, fiqh, tasawuf dan lain sebagainya. Hampir-hampir tidak ditemukan, khususnya di kalangan pesantren tradisional yang mengajarkan seluruh kitab dengan berbagai disiplin itu sekaligus. Jika santri sudah menamatkan sebuah bidang keilmuan (kitab), biasanya para kiai akan merekomendasikan santri tersebut untuk melanjutkan pendidikannya ke kiai (pesantren) lain untuk mendalami bidang disiplin keagamaan yang tidak diajarkan di pesantren tersebut. Maka tidaklah mengherankan jika ditemukan ada seorang kiai atau santri yang menguasai berbagai disiplin keilmuan memiliki banyak guru dari berbagai pesantren yang pernah disinggahinya.

Memang tidak semua pesantren mengajarkan tarekat. Pendidikan tarekat lazimnya diajarkan di pesantren-pesantren yang bercirikan tradisional, dan tidak diajarkan pada pesantren modern. Sementara itu tidak semua kiai juga menjadi mursyid tarekat. Karena untuk mencapai derajat mursyid tidak cukup hanya seseorang memiliki kecakapan intelektualitas, keluhuran budi dan memiliki koneksi (nasab) keilmuan dengan syeikh. Menjadi seorang mursyid dibutuhkan pengakuan yang bersifat lahir dan batin.

Bagaimanapun pesantren memiliki mileu yang relevan bagi pertumbuhan tarekat di Indonesia. Kehidupan bersama di asrama antara para santri dan kiai justru memudahkan adanya proses transfer pengetahuan. Di asrama (pondok), para kiai dapat membangun disiplin dan mengontrol aktivitas santrinya dengan mudah. Oleh sebab itu terbangunlah $a d a b$ di lingkungan pesantren dalam bentuk ketaatan para santri kepada kiai. Bagaimanapun tarekat mula-mula dibangun berdasarkan adab dan ketaatan seorang murid dengan mursyid. Seorang murid di hadapan mursyid digambarkan seperti sebujur jenazah yang sedang dimandikan dan dikafankan. Artinya dia harus taat dan pasrah dengan setiap ketentuan yang diajarkan dalam tarekat oleh gurunya. Bagaimanapun tarekat tidak hanya dibangun di atas praktek seperti riyâdlah dan $d z i k r$, tapi juga aspek etis keagamaan. Latihan ruhani berupa dzikir itu memang memiliki maksud sebagai tangga atau jalan 
yang dipaparkan para mursyid ke murid untuk mencapai Allah. Tapi hakikat tarekat itu sendiri sesungguhnya, sebagaimana disampaikan oleh banyak ulama tarekat, tidak untuk mendapatkan makrifah setelah berkembara menuju Allah. Buah tarekat ada pada akhlak, dan akhlak adalah tujuan dari semua kewajiban menjalankan syariah.

Di lingkungan pesantren, para kiai yang merangkap sebagai mursyid tarekat memberikan bimbingan di antaranya adalah riyâdlah-riyâdlah seperti dzikirdzikir dan proses taqarrub kepada Allah. Di samping itu, kiai mampu menilai maqam yang telah dilalui oleh para santri sebagai bahan evaluasi apakah perjalanan yang telah ditempuh itu dapat dilanjutkan ke maqâm selanjutnya dan lain sebagainya. Riyâdlah yang dipraktekkan oleh seorang santri harus didasarkan pada tingkat kepercayaan yang tinggi kepada seorang kiai. Bagaimanapun kiai tidak mungkin menggiring santrinya jauh tersesat dari jalan syariat yang telah ditegaskan dalam Islam. Hal ini dapat dinisbatkan pada tingkat kepercayaan dan ketaatan mutlak para sahabat kepada Nabi.

Praktek-praktek riyâdlah pada tarekat tidak berhenti pada aktivitas $d z i k r$ dan lain sebagainya. Bahkan dalam waktu-waktu tertentu, di pesantren, dibacakan manâqib terhadap para syeikh pendiri tarekat untuk mengenang dan menjabarkan silsilah tarekat yang diajarkan di sebuah pesantren. Bahkan untuk menghormati guru-guru yang mengajarkan tarekat itupun juga diadakan acara hawl. Segenap acara yang digelar itu semakin menunjukkan silsilah keilmuan tarekat yang diperoleh oleh seorang kiai di pesantren. Di samping itu, sebelum ritual $d z i k r$ dilakukan biasanya para jamaah akan bertawâshul terhadap para mursyid dan syeikh yang telah mengajarkan dan menyebarkan tarekat sampai kemudian diterima oleh kiai dan diamalkan oleh para santri di lingkungan pesantren. Inilah yang menyebabkan nilai-nilai tarekat tumbuh subur di Indonesia dan hingga kini daunnya tetap rimbun menyejukkan hati bagi siapa saja yang berteduh di bawahnya. Di samping itu, buah yang tumbuh di dahan, rasanya selalu manis hingga menyejukkan tenggorokan kita.

\section{KESIMPULAN}

Kedatangan Islam ke bumi Nusantara melalui jalur tarekat justru membuat Islam semakin kaya dan memiliki wajah yang khas dibandingkan dengan di belahan dunia Islam lainnya. Tarekat mampu tumbuh subur, sementara di belahan dunia lain, tarekat tumbuh dan tenggelam seiring dengan perubahan rezim atau kekuasaan. Tarekat mendapatkan lingkungannya yang tepat di Indonesia di pesantren. Memang tidak semua pesantren di 
Indonesia mengajarkan tarekat, tapi mileu pesantren menjadi tanah yang subur bagi pertumbuhan tarekat. Dari pesantren itulah di masa modern ini tarekat menyebar dan bermetamorfosis ke dalam praktekpraktek urban sufisme yang kini tengah gencar di kalangan masyarakat modern perkotaan.

\section{REFERENSI}

Aboeakar Atjeh, (1985). Pengantar Ilmu Tarekat: Uraian tentang Mistik, Solo: Ramadhani.

Abu al-Wafa' al-Ghanimi alTaftazani, (1997). Sufi dari Zaman ke Zaman, terj. Ahmad Rofi' Utsmani, Bandung: Pustaka.

Ahmad Muhakamurrohman, "Pesantren: Santri, Kiai dan Tradisi". (2014). Ibda: Jurnal Kebudayaan Islam, Vol. 12, No. 2, Juli-Desember 2014

Annemerie Schimmel, (1986).

Dimensi Mistik dalam Islam, terj. Sapardi Djoko Damono dkk., Jakarta: Pustaka Firdaus, Azyumardi Azra, (2002). Jaringan

Global dan Lokal Islam Nusantara, Bandung: Mizan, , (20070). Jaringan Ulama

Timur Tengah dan Kepulauan Nusantara Abad XVII dan XVIII: Akar Pembaruan Islam Indonesia edisi revisi, Jakarta: Kencana Prenada Media Group,
Fazlur Rahman, (1997). Islam, terj. Ahsin Muhammad, Bandung: Pustaka.

Ira M. Lapidus, (2000). Sejarah Sosial Ummat Islam, Bagian Kesatu dan Dua, Terj. Ghufron A. Mas'adi, Jakarta: Rajagrafindo Persada.

J. Spencer Trimingham, (1999). Mazhab Sufi, terj. Luqman Hakim, Bandung: Pustaka.

Karel A. Steenbrink, (1994). Pesantren, Madrasah dan Sekolah: Pendidikan Islam dalam Kurun Modern, Jakarta: LP3ES.

----------, (1984). Aspek-aspek tentang Islam di Indonesia Abad Ke-19, Jakarta: Bulan Bintang,

Lindung Hidayat Siregar. (2009). "Sejarah Tarekat dan Dinamika Sosial", Miqot, Vol. XXXII, No. 2, Juli-Desember,

Martin van Bruinessen, (2012). Kitab Kuning dan Pesantren, terj. Farid Wajidi dkk., Yogyakarta: Gading Publishing, , edisi revisi

(1992). Tarekat Naqsyabandiyyah di Indonesia, Bandung: Mizan,

Musthofa, (2015). "Kedatangan Islam dan Pertumbuhan Pondok Pesantren di Indonesia: Perspektif Filsafat Sejarah", An-Nuha, Vol. 2, No. 1, Juli 
Nor Huda, (2015). Sejarah Sosial Intelektual Islam di Indonesia, Jakarta: Rajawali Press,

Nurcholish Majdid, (1992). Islam, Doktrin dan Peradaban, Jakarta: Yayasan Wakaf Paramadina.

--, (2004). Indonesia Kita, Jakarta: Universitas Paramadina Press,

---------, (2000). Islam Agama Peradaban: Membangun Makna dan Relevansi Doktrin Islam dalam Sejarah, Jakarta: Yayasan Wakaf Paramadina,

Sartono Kartodirjo, (1984). Pemberontakan Petani Banten 1888, Jakarta: Pustaka Jaya, Suddin Bani. (2015). "Kontribusi Pesantren dalam Sistem Pendidikan Nasional", Auladuna, Vol. 2, No. 2, Desember

Zamakhsyari Dhofier, (2015). Tradisi Pesantren: Studi Pandangan Hidup Kyai dan Visinya Mengenai Masa Depan Indonesia, Jakarta: LP3ES, , edisi revisi. 